\title{
Cardiac stem and progenitor cells as a potential therapeutic agent for the treatment of damaged cardiac muscle
}

\author{
Piotr Michał Wilczek ${ }^{1}$, Marian Zembala ${ }^{2}$, Michał Zembala², Aldona Mzyk ${ }^{1}$, Tomasz Cichoń $^{3}$, \\ Ryszard Smolarczyk ${ }^{3}$
}
${ }^{1}$ Foundation for Cardiac Surgery Development in name of Professor Zbigniew Religa, Bioengineering Laboratory in Zabrze
${ }^{2}$ Silesian Center for Heart Diseases, Department of Cardiac Surgery and Transplantation in Zabrze, Silesian Medical University, Katowice
${ }^{3}$ Center of Translational Research and Molecular Biology of Cancer, Maria Sklodowska-Curie Memorial Cancer Center and Institute of Oncology in Gliwice

Kardiochirurgia i Torakochirurgia Polska 2013; 10 (1): 51-61

\begin{abstract}
Background: Specific cardiac stem cells/progenitor cells (CSCs/ CPCS) are multipotent and clonogenic, giving rise to cardiomyocytes, smooth muscle cells and endothelial cells. These cells can be used in cell therapy for the treatment of diseased heart tissue, but there is a need for an effective isolation process, and characterization of the phenotype and morphology of the isolated cells, to increase the potential therapeutic use of this type of cells.

Aim of the study: The aim of this study was to isolate the CSCS/ CPCs from the tissue fragments derived from explanted heart, and characterize the phenotype and morphology of the isolated cells.

Material and methods: Myocardial tissue samples were taken from explanted hearts under sterile conditions. After the cells had grown to confluence, they were detached by gentle enzymatic digestion and seeded on poly-D-lysine-coated dishes. Using flow cytometry methods the phenotype of the isolated cells was analyzed. Applying phase contrast and fluorescent microscopy techniques the morphology of the cells and growth characteristics were evaluated.

Results: The isolated cells showed the CSCs/CPCs phenotype expressing the c-kit receptor, Nkx 2.5, MDR-1, and GATA-4. The cells were also positive for mesenchymal stem cell receptors including CD90, CD105, CD73 and CD144. Only a few cells were positive for the Lin-1, Lin-2 and Lin-3 receptors. The growth characteristics and cell morphology differ depending on the place of isolation.

Conclusions: The CSCS/CPCs seems to have a great therapeutic potential, but there is a need for a full description of phenotype, morphology and growth characteristics.

Key words: cardiac stem cells, heart disease, cell culture.
\end{abstract}

\section{Streszczenie}

Wstęp: Sercowe komórki macierzyste/progenitorowe (cardiac stem cells/progenitor cells - CSCS/CPC) są multipotencjalną, klonogenną pulą komórek zdolnych do różnicowania się w kardiomiocyty, komórki mięśniówki gładkiej i komórki śródbłonka. Komórki te mogą być stosowane w terapii uszkodzonego mięśnia sercowego, konieczne jest jednak właściwe prowadzenie procesu izolacji, charakterystyka fenotypu i morfologii izolowanych komórek, co może zwiększać potencjał terapeutyczny związany z ich zastosowaniem. Cel pracy: Celem pracy była izolacja CSCS/CPC z fragmentów tkanki pochodzących z różnych obszarów mięśnia sercowego, charakterystyka ich fenotypu i cech morfologicznych.

Materiat i metody: Fragmenty tkanki do izolacji pobierano z eksplantowanego serca w warunkach sterylnych. Po osiągnięciu konfluentnej hodowli komórki były trawione i przenoszone na podłoże z poli-D-lizyną. Przy użyciu technik cytometrii przepływowej oceniano fenotyp izolowanych komórek, stosując metody mikroskopii w kontraście fazowym oraz mikroskopii fluorescencyjnej, oceniano morfologię komórek.

Wyniki: Izolowane komórki wykazywały fenotyp CSCS/CPC z obecnością receptora c-kit, Nkx 2.5, MDR-1 oraz GATA-4. Charakteryzowały się również pozytywną reakcją wobec receptorów komórek mezenchymalnych, w tym CD90, CD105, CD73, CD144. Nieliczne komórki wykazywały ekspresję receptorów Lin-1, Lin-2, Lin-3. Charakterystyka wzrostu i morfologia komórek różniły się w zależności od miejsca ich pobrania.

Wnioski: Wydaje się, że komórki CSCS/CPC mają istotny potencjał terapeutyczny, jednak konieczny jest ich pełny opis pod względem fenotypowym, morfologicznym oraz charakterystyki wzrostu.

Słowa kluczowe: sercowe komórki macierzyste, choroby serca, hodowle komórkowe. 


\section{Introduction}

Cardiac stem cells (CSCs) are multipotent cells capable of differentiation into cardiomyocytes, endothelial cells and smooth muscle cells. These cells are characterized by the presence of c-kit (CD117) and MDR-1 surface receptors, and are negative for the markers of hematopoietic cells. The discovery of CSCs revolutionized the perception of the heart muscle, as an organ not capable of regeneration. Currently, it is believed that aging cardiac muscle cells such as cardiomyocytes, coronary forming cells and stromal cells are constantly replaced by the cardiac stem cells. Cardiac stem cells and progenitor cells are located in niches - intercellular spaces of strictly specialized function and morphology, in which they mature, divide and differentiate. Niches are scattered in the area of ventricular fibrillation and the heart, but the largest concentration was observed in the left ventricular apex and within the atrial muscle. Cardiac stem cells' participation in the physiology and pathophysiology of heart disease is still a subject of intense research. It is known, however, that the increased proliferation of CSCs contributes to cardiac hypertrophy. However, the huge potential for cardiac regeneration appears to be inadequate in terms of ischemia. The rapid increase in the levels of growth factors (insulin-like growth factor - IGF, hepatocyte growth factor - HGF, fibroblast growth factor beta - bFGF) and chemotactic factors observed in the ischemic area suggests an important role of these factors in the migration of progenitor cells to the site of injury.

The aim of this study was to evaluate a method of isolating cardiac stem cells from fragments originating from the myocardium explanted hearts. Also the phenotype of isolated cells and their morphological characteristics were evaluated.

\section{Material and methods}

\section{Isolation and culture of cardiac stem cells}

Cardiac stem cells were isolated using the enzymatic method according to Messina and colleagues. Briefly, cardiac muscle tissue derived from explanted heart was cut into 1-2 $\mathrm{mm}^{3}$ pieces and washed in phosphate buffered saline (PBS) without $\mathrm{Ca}^{2+}$ or $\mathrm{Mg}^{2+}$ several times to remove the contaminating fat and red blood cells. After washing, the tissue was digested using a solution of $0.2 \%$ trypsin/EDTA plus $0.1 \%$ collagenase IV for $5 \mathrm{~min}$ at $37^{\circ} \mathrm{C}$; the procedure was repeated 3 times. After isolation, the cells were discarded, and the remaining tissue fragments were washed in IMDM medium (Iscove's Modified Dulbecco's Medium) supplemented with $10 \%$ fetal calf serum (FCS), $20 \mathrm{U} / \mathrm{ml}$ penicillin G, $20 \mathrm{mg}$ / $\mathrm{ml}$ streptomycin and $2 \mathrm{mmol} / \mathrm{l} \mathrm{L-glutamine.} \mathrm{After} \mathrm{washing,}$ the tissue fragments were moved onto culture dishes and incubated at $37^{\circ} \mathrm{C}$ with $5 \% \mathrm{CO}_{2}$. After a period of approximately 2-3 weeks, a fibroblast-like layer was generated, over which small, round, phase-bright cells were observed. The phase-bright cells were collected through two washes in PBS without $\mathrm{Ca}^{2+}$ or $\mathrm{Mg}^{2+}$ (1-2 $\left.\mathrm{min}\right)$, one wash in
$0.53 \mathrm{mmol} / \mathrm{I} \mathrm{EDTA}$, and finally one wash in a $0.5 \mathrm{~g} / \mathrm{l}$ trypsin and $0.53 \mathrm{mmol} / \mathrm{I}$ EDTA solution (2-3 $\mathrm{min}$ ) at room temperature. The harvested cells were transferred to culture plates coated with poly-D-lysine and cultured in a mix of IMDM medium (35\%) and DMEM-HAM F12 medium (65\%) supplemented with $1 \%$ L-glutamine, $20 \mathrm{ng} / \mathrm{ml} \mathrm{bFGF,} \%$ B27, $4 \mathrm{ng} / \mathrm{ml}$ cardiotrophin, $10 \mathrm{ng} / \mathrm{ml} \mathrm{EGF,} 40 \mathrm{nM} / \mathrm{l}$ thrombin, and 0.2\% mercaptoethanol.

\section{Phenotype analysis}

The cells for the flow cytometry analysis were detached from the cell culture dishes using 0.5\% EDTA solution. Cells were then washed twice in PBS. The total cells of $2 \times 10^{5}$ cells $/ \mathrm{cm}^{2}$ were incubated with the primary antibody conjugated for $60 \mathrm{~min}$ at room temperature. The following receptors were analyzed: c-kit, NKX 2.5, MDR-1, GATA4, CD90, CD45, CD31, CD73, CD105, CD144, Lin-1, Lin-2 and Lin-3. The Beckman Coulter FC 500 flow cytometer with MXP software (Beckman Coulter) was used for the sample acquisition and analysis.

\section{The study of growth and morphology of isolated and cultured cardiac cells}

At each stage of the culture the morphology of isolated cells was identified using the phase-contrast Plas-DIC microscopy technique. In order to fully identify cells the fluorescence microscopy technique was used. Observations of cell growth in the culture were performed. For this purpose, in the cell cultures the rate of cell migration was observed, and after a cell monolayer was formed around the tissue (for about 2 weeks in culture) the growth rate of the cells was assessed by quantitative assessment, each time from five tissue fragments. Also such parameters as changes of the direction of cell growth in culture and changes in shape index as the expression of cell-cell function were evaluated by the formula:

$4 \pi \mathrm{A} / \mathrm{p} 2$

Where:

$A=$ area of the cell

$\mathrm{p}=$ cell circuit.

Observations were made using an Axio Observer microscope and for the data analysis AxioVision 4.6 (Zeiss) software was used.

\section{Results}

\section{Isolation and culture of cardiac stem cells}

In the primary cultures of myocardial derived tissue fragments the fibroblastic cell migration was observed after 2 weeks of culture. After 3-4 weeks (depending on the donor) formation of a monolayer of fibroblast cells was observed. Over the monolayer of fibroblast cells small round cells with progenitor/stem morphology were observed. Cells from the primary culture were then transferred to the poly-D-lysine coated dishes. On the poly- 
D-lysine the formation of a cardiosphere was observed and also a capillary-like structure was formed which can indicate a tendency of these cells to spontaneously differentiate into endothelial cells and the initiation of angiogenesis (Fig. 1). Staining of the cardiosphere using c-kit antibody results in a positive reaction for the stem cell receptor (Fig. 2, 3).

\section{Phenotype analysis}

Flow cytometry analysis of the isolated cells indicated that about $7 \%$ of the cells were c-kit positive, some of the cells expressed the Nkx 2.5 receptor specific for the cardia myocyte, and additionally the presence of MDR-1 and GATA-4 positive cells was observed (Fig. 4). A significant percentage of the cells exhibited a positive reaction to the mesenchymal cell specific receptors: more than $80 \%$ were CD90 positive, while the percentage of CD105 and CD144 positive cells was $97.1 \%$ and $98.1 \%$ respectively. The percentage of Lin-2 and Lin-3 cells did not exceed 3\% (Fig. 5, 6).

\section{The study of growth and morphology of isolated and cultured cardiac cells}

In the study of cell morphology the examination of growth characteristics was included. The morphological parameters of the cells in the culture were tested in relation to the time of the culture and place of isolation. The study included the changes in cell surface area, perimeter, shape index, and growth area. It was observed that the average time to start the migration from the tissue was one week. The highest rate of growth of cells in primary culture was observed between 7 and 11 days of the culture. In a further period the rate of growth was significantly reduced,
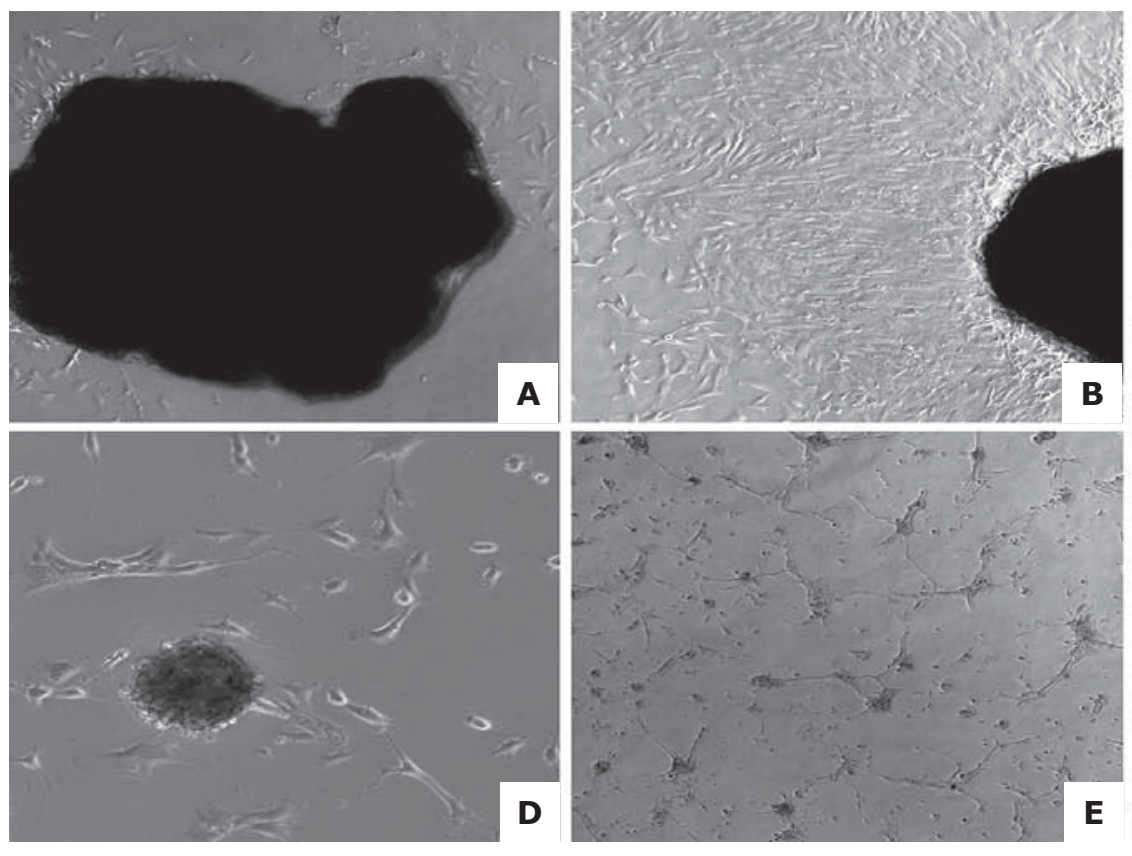
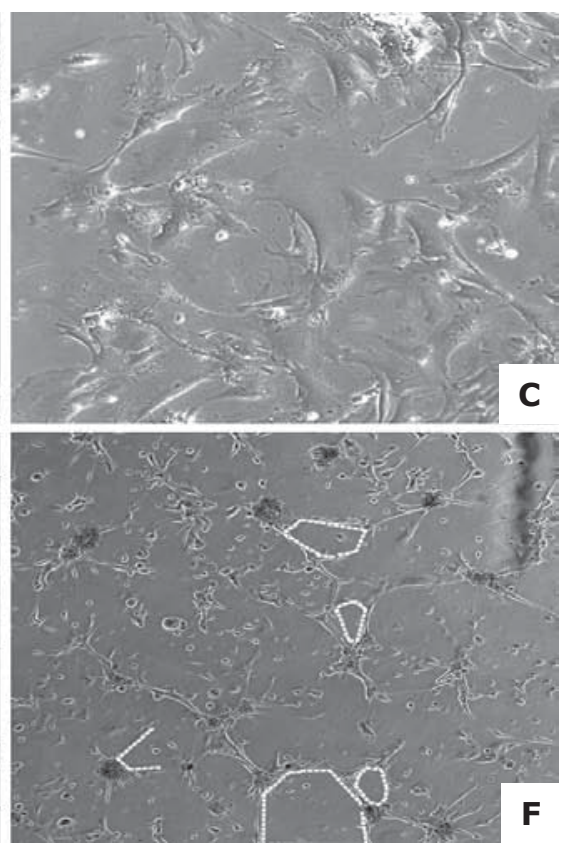

Fig. 1A-F. Primary and secondary culture of cardiac stem cells derived from tissue explants. A. Formation of cell monolayer around tissue fragments, small round cells with cardiac stem cell morphology. B, C. Cells from the primary culture between P1-P3 passage form cardiospheres. D, E. In the secondary culture the capillary-like structure is observed
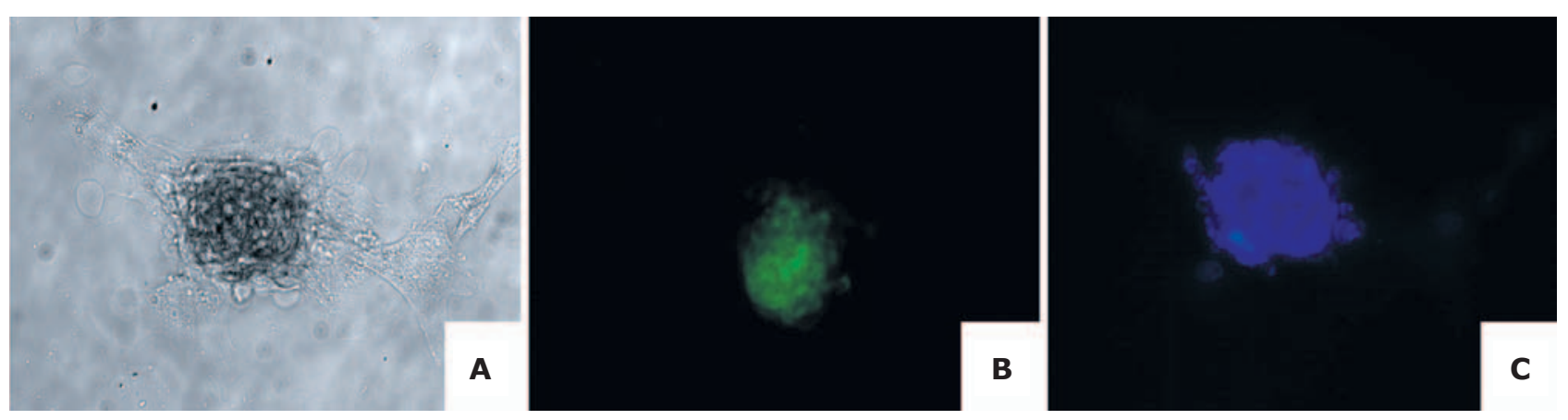

Fig. 2A-C. The cells in the secondary culture form a cardiosphere (A), positive reaction for the c-kit antibody (B), cells stain with the DAPI dye $(C)$ 

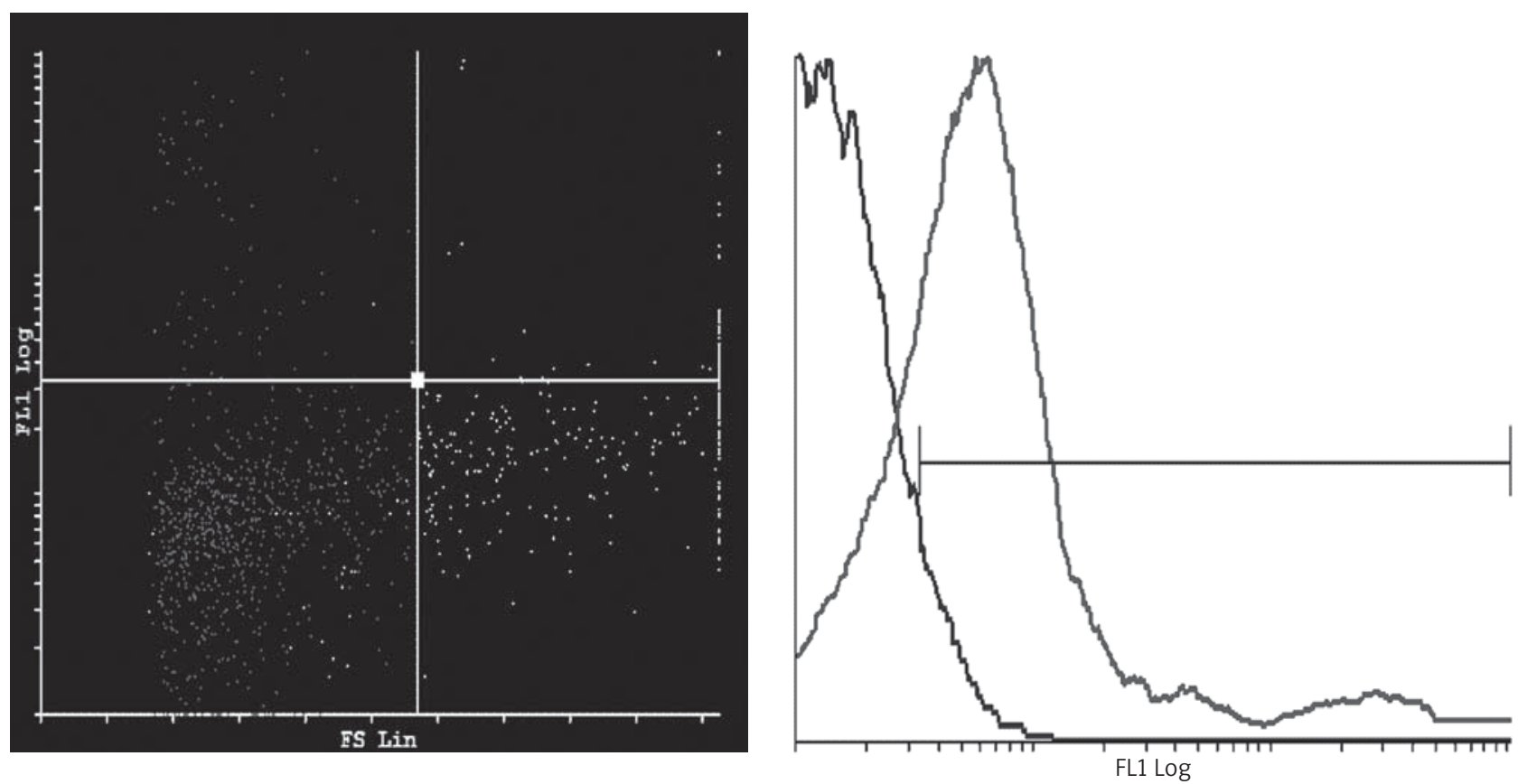

Fig. 3. Flow cytometry analysis of the c-kit positive cells (blue line - isotype control, green line - c-kit positive sample)

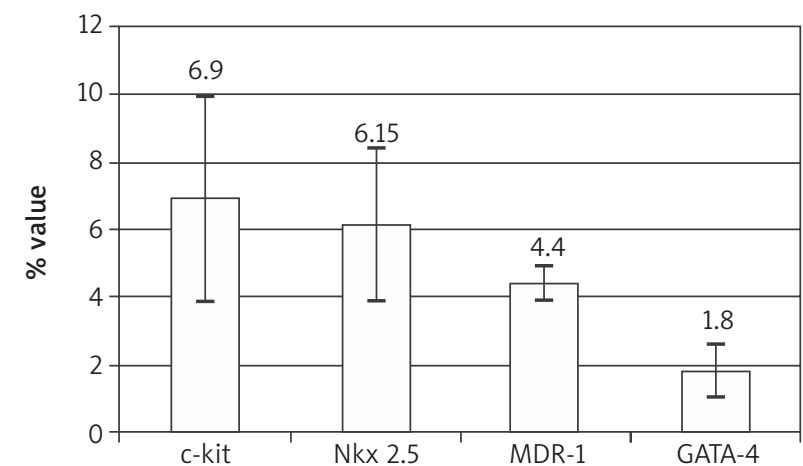

Fig. 4. The percentage of c-kit, Nkx 2,5, MDR-1, GATA-4 positive cells in the cell culture of cardiac stem cells

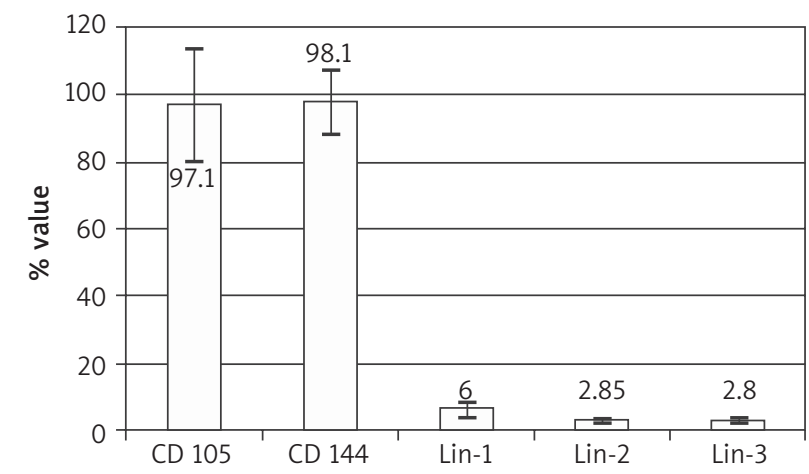

Fig. 6. The percentage of CD105, CD144, Lin-1, Lin-2, Lin-3 positive cells in the cell culture of cardiac stem cells

mainly due to contact inhibition. Similar relationships were observed for cell shape index (Fig. 7, 8).

A significant increase in growth in relation to the absence of changes in cell perimeter may indicate that in-

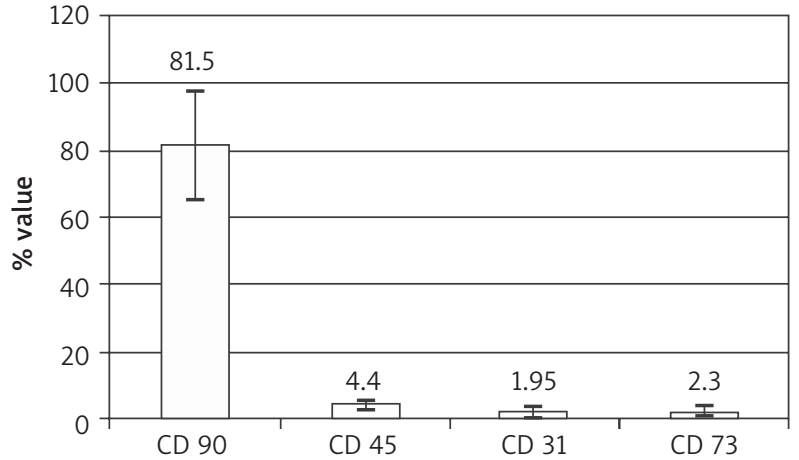

Fig. 5. The percentage of CD90, CD45, CD31, CD73 positive cells in the cell culture of cardiac stem cells

crease of growth area at different days of culture is the result of increased numbers of cells rather than an increase in their cell volume.

The characteristics of cardiosphere growth were also analyzed in secondary culture. The highest percentage increase in the size of the cardiosphere was observed between days 3 and 9 of the secondary culture. After about 2 weeks, the average size of the cardiosphere reached about $170 \mathrm{~mm}$; this value remained constant. A single cardiosphere reached $300 \mathrm{~mm}$ in size (Fig. 10).

Microscopic evaluation of cells in the culture derived from different sites of myocardial tissue indicates that the cells differ in morphology in both the primary and secondary culture (Fig. 11-15).

Also in the case of secondary culture on the poly-D-lysine the changes in the morphology of the cells in relation to the sites of isolation were observed. The differences in morphology were assessed on the basis of cell area, perimeter, growth area, and shape (Fig. 16-35). 


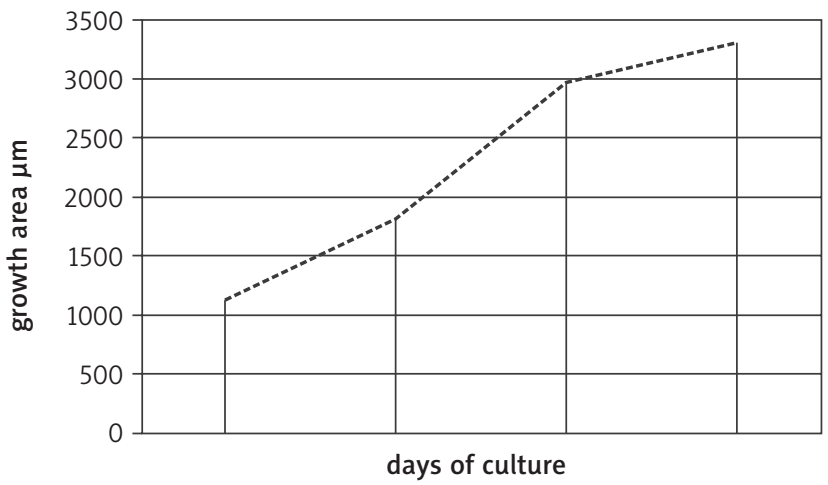

Fig. 7. Changes in cell growth on different days $(3,7,8,11$ days of culture) in primary culture

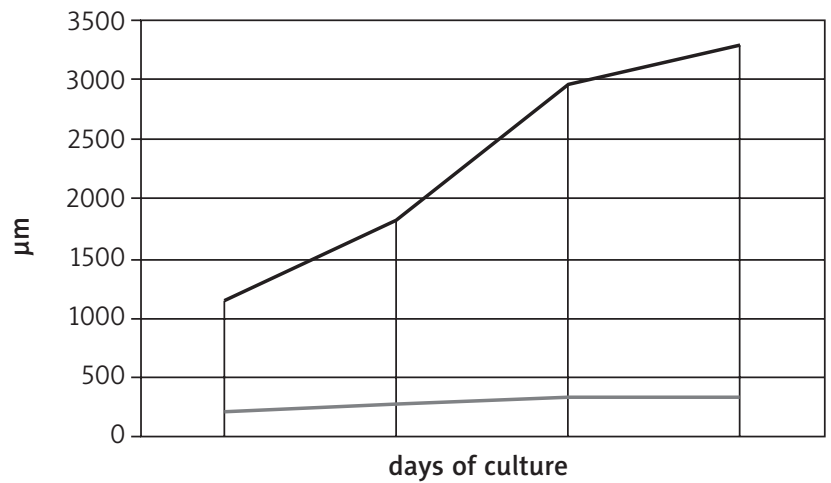

Fig. 9. Changes of growth area in relation to perimeter on different days $(3,7,8,11$ days of culture) in primary culture (growth areablack line, perimeter - grey line)

\section{Discussion}

Cells capable of self-renewal and bearing the potential of developmental plasticity have recently been shown to reside in the myocardium. These CSCS/CPCs are multipotent and clonogenic, giving rise to cardiomyocytes, smooth muscle cells and endothelial cells both in vivo and in vitro. The use of CSCS/CPCs in cell therapeutic applications for the reconstruction of ischemically altered heart tissue is very promising. The number of cardiac stem cells is controversial. From the studies on mice, rats, humans and dogs it was indicated that there is 1 cardiac stem cell to about 8000 to 20000 cardiac myocytes [1-4]. The controversy also concerned the phenotype of cardiac stem cells. In some studies the presence of Sca-1 receptor on the stem cells was reported [4] while in another study the presence of c-kit positive cells was described [5]. The c-kit positive cells which are capable of regeneration of diseased heart are a component of human and dog heart $[6,7]$. It is also not clear if the stem cells derived from heart have the mesenchymal cell phenotype. In the study of Smith et al. [8] the percutaneous cardiac biopsy was used for the culture of cardiosphere-derived cells. The isolated cells in the secondary culture express the c-kit receptor but also express the CD105, CD90, CD31 and CD34 receptors. The majority of the cells were MDR-1, CD133 and CD45 negative, which may indicate that the cardiac stem cells are not of

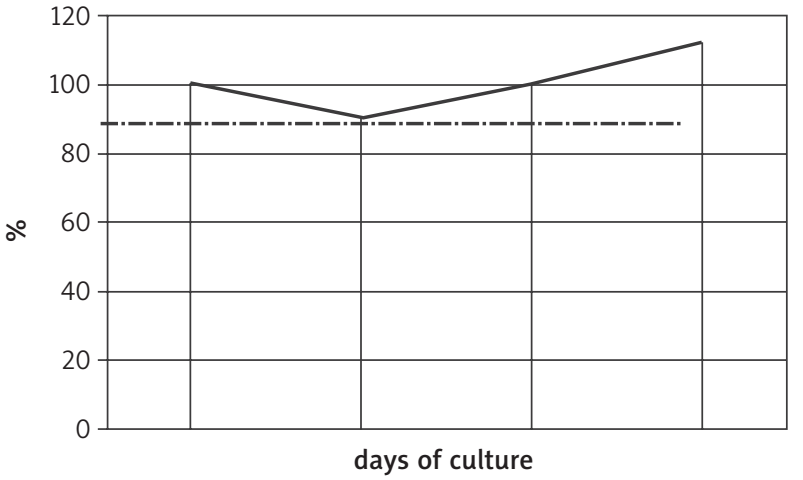

Fig. 8. Percentage changes in shape index on different days $(3,7$, 8,11 days of culture) in primary culture

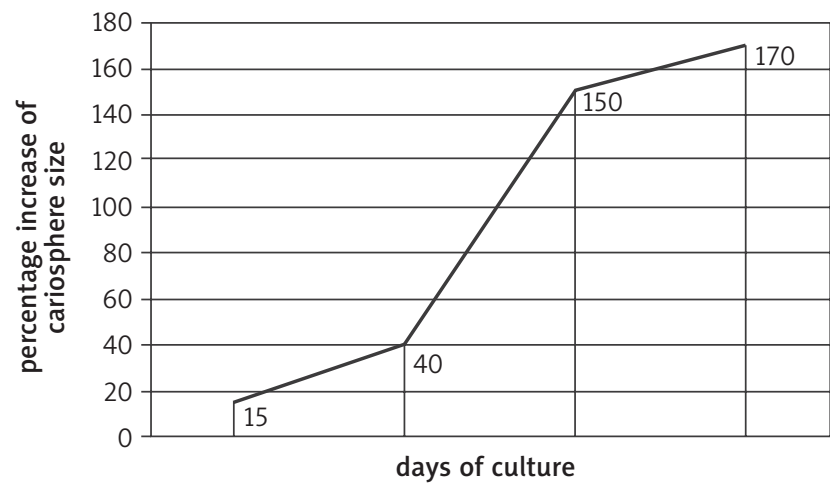

Fig. 10. Percentage increase in cardiosphere size on different days of secondary culture on the poly-D-lysine coated dishes

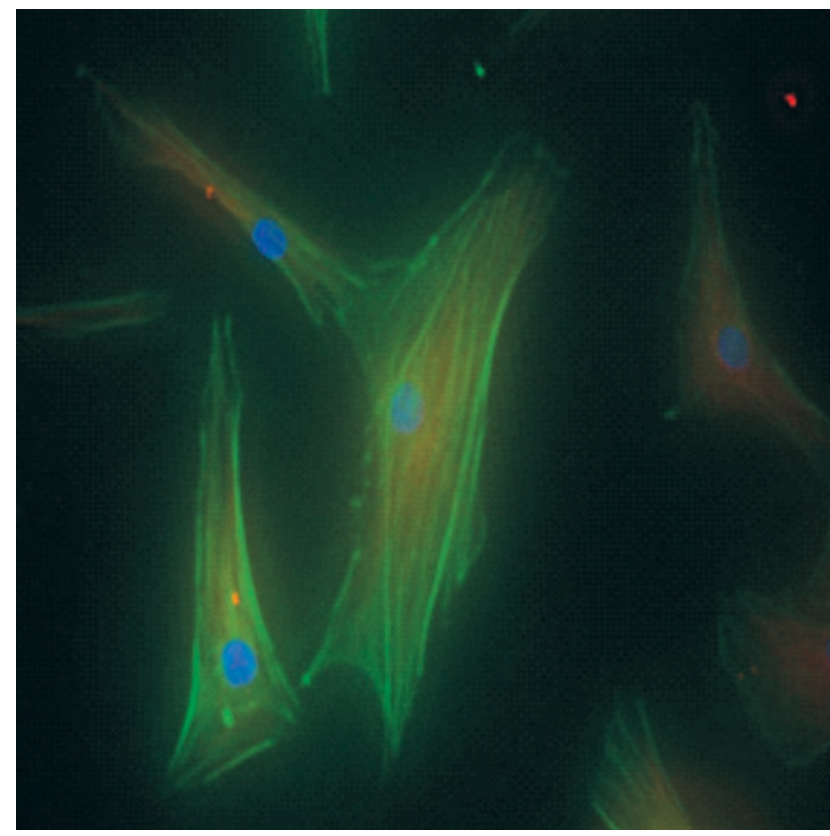

Fig. 11. Fluorescence microscopy image of cells isolated from the apex of the heart in primary culture. FITC conjugated phalloidin which stained actin filaments (green fluorescence), nuclear cytoskeleton - PE conjugated vimentin (red fluorescence) and nuclei stained with DAPI (blue fluorescence) 


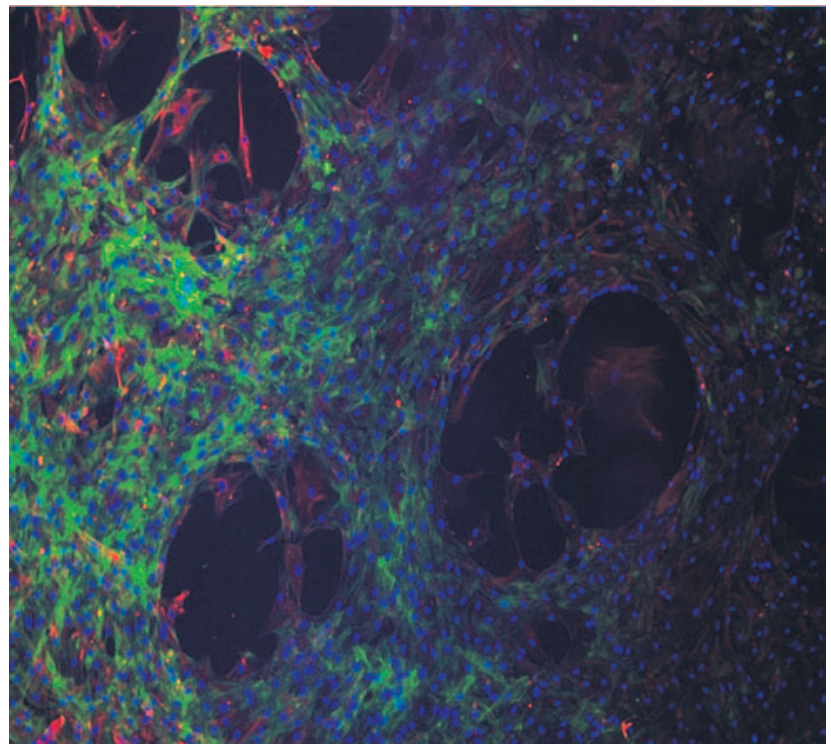

Fig. 12. Fluorescence microscopy images of cells isolated from the left ventricle in primary culture. FITC conjugated phalloidin which stained actin filaments (green fluorescence), nuclear cytoskeleton - PE conjugated vimentin (red fluorescence) and nuclei stained with DAPI (blue fluorescence)

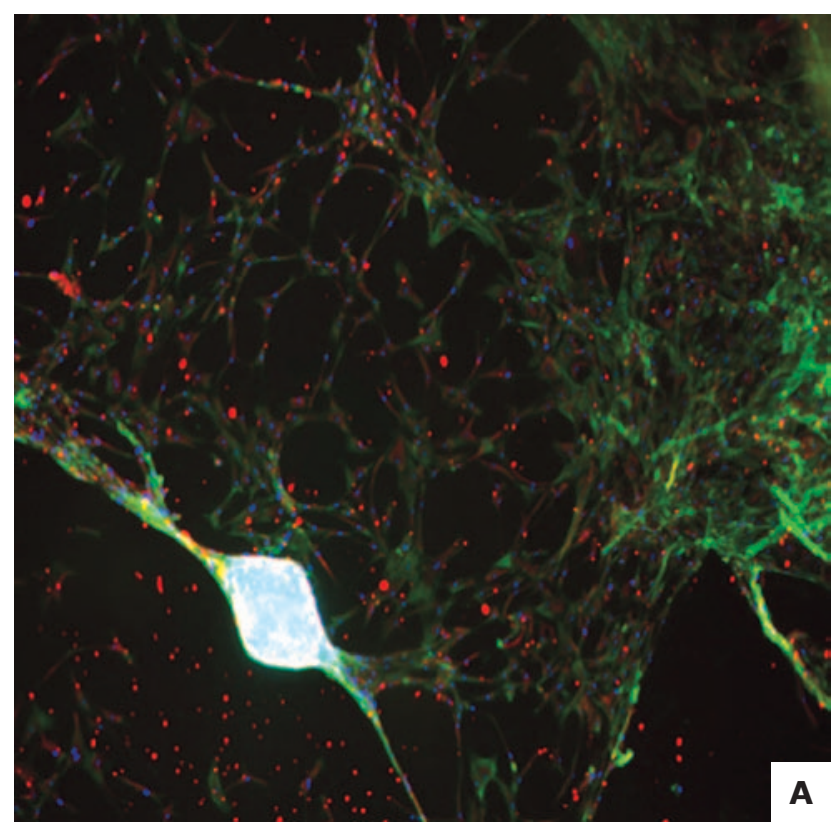

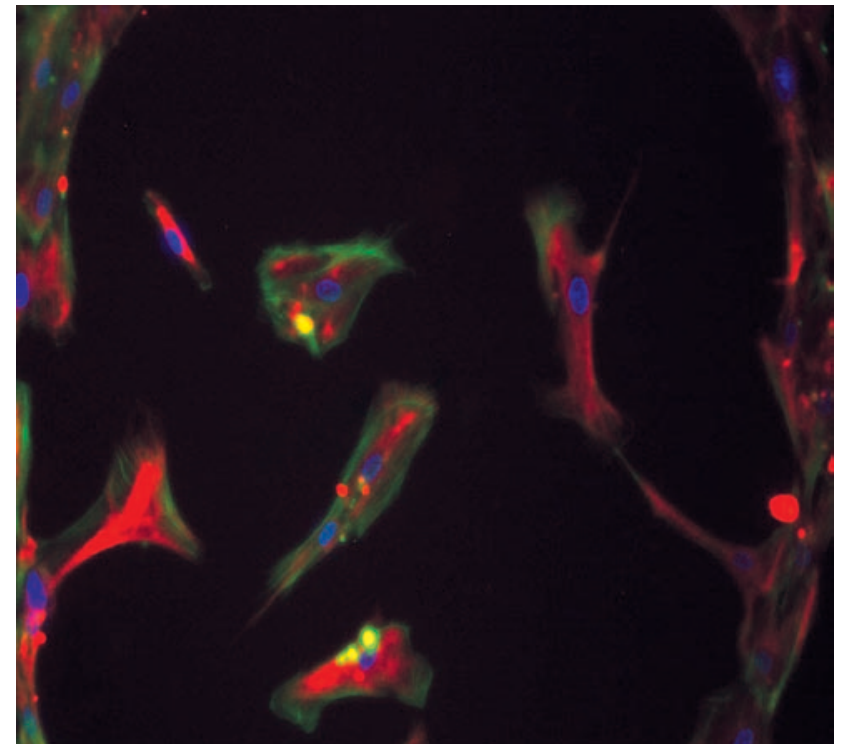

Fig. 13. Fluorescence microscopy images of cells isolated from the right ventricle in primary culture. FITC conjugated phalloidin which stained actin filaments (green fluorescence), nuclear cytoskeleton - PE conjugated vimentin (red fluorescence) and nuclei stained with DAPI (blue fluorescence)

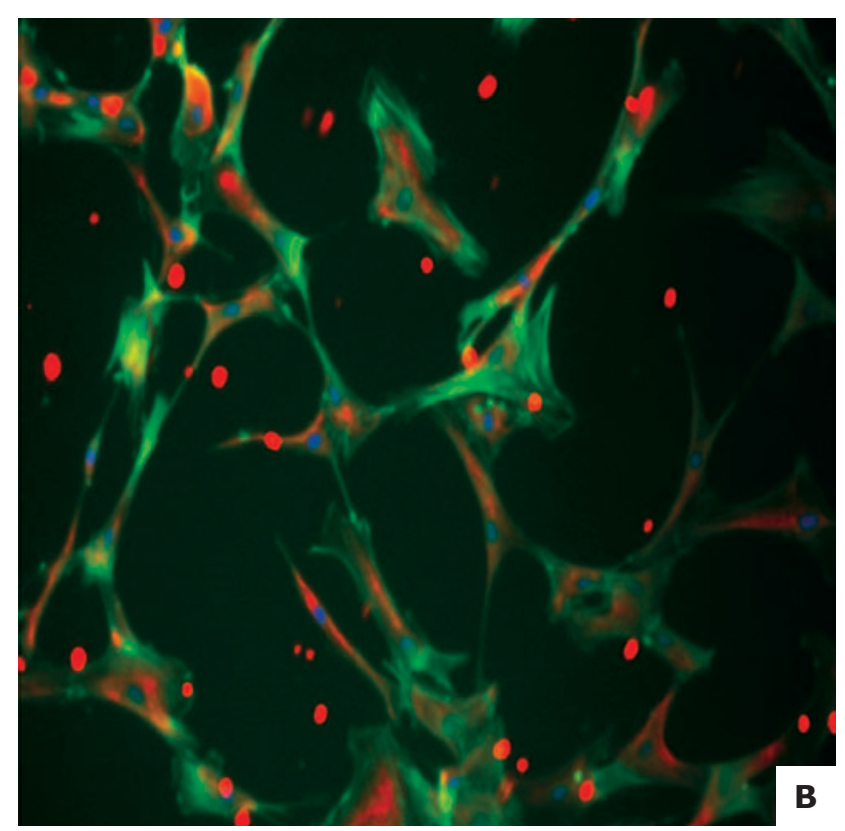

Fig. 14A-B. Fluorescence microscopy images of cells isolated from the right atrium in primary culture. FITC conjugated phalloidin which stained actin filaments (green fluorescence), nuclear cytoskeleton - PE conjugated vimentin (red fluorescence) and nuclei stained with DAPI (blue fluorescence)

hematopoietic cell origin. It was suggested in the study that the mesenchymal stem cell existing in the cardiosphere-derived structure can act as a physical and secretory support for the cardiac stem cells. In the study of Tateishi et al. [9] it was found that human cardiac stem cells rarely expressed c-kit receptors and CD45, CD31 and CD34 receptors but they indicated that the majority of the cells expressed the mesenchymal stem cell phenotype CD90, CD105, CD29, CD73 and CD71, and they also expressed vimentin and collagen I.
The results obtained in our study were similar to those of Smith et al. [8] and Tateishi et al. [9]. We observed that the cardiosphere forming cells obtained in the secondary culture expressed c-kit, but the majority of the cells were positive for mesenchymal stem cell receptors CD90, CD105 and CD144, and they were negative for the hematopoietic phenotype because only a small percentage of CD45 and CD31 positive cells was observed. The study in relation to the studies from other laboratories can confirm the thesis 

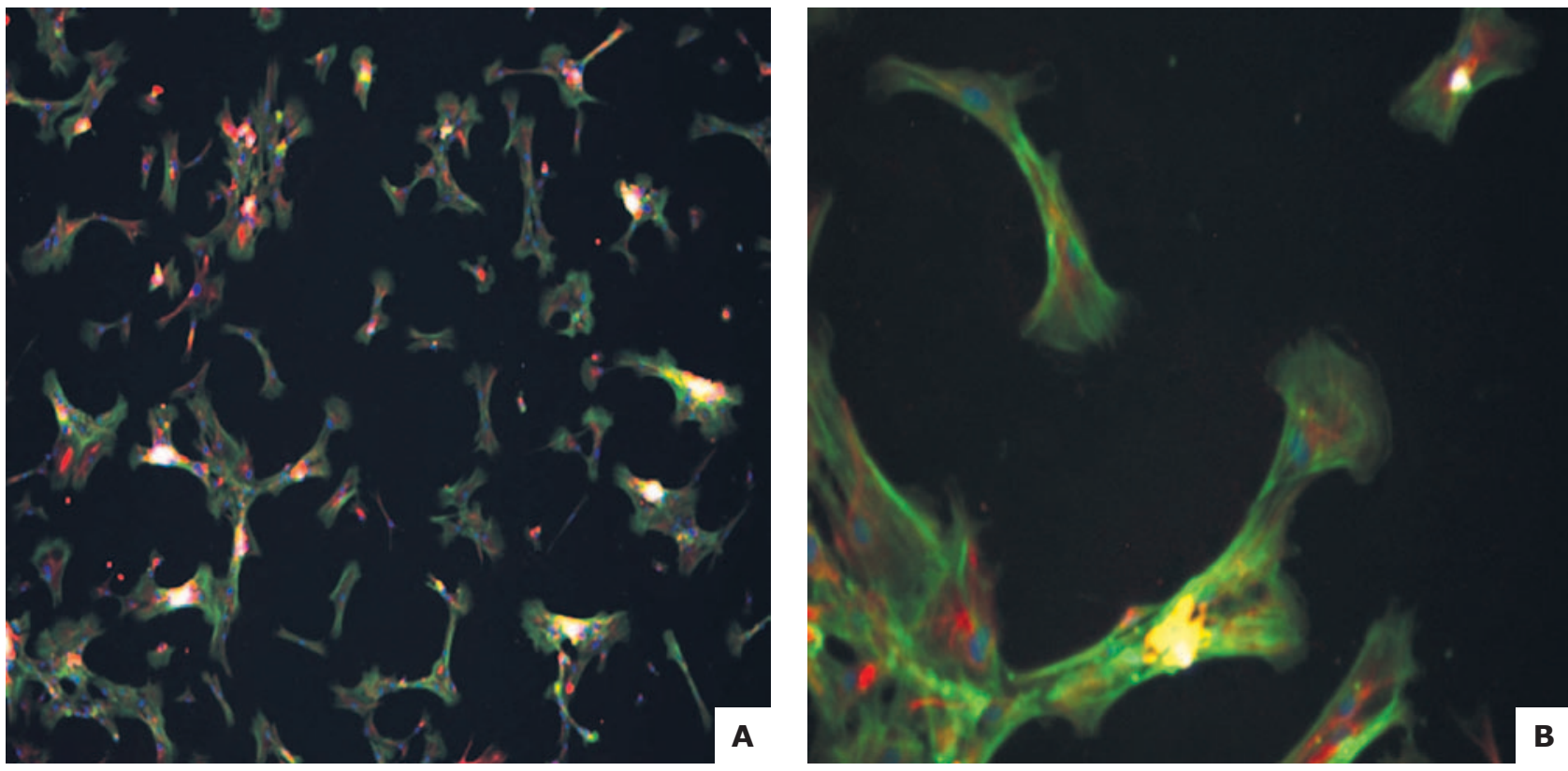

Fig. 15A-B. Fluorescence microscopy photography of cells isolated from the septum in primary culture. FITC conjugated phalloidin which stained actin filaments (green fluorescence), nuclear cytoskeleton - PE conjugated vimentin (red fluorescence) and nuclei stained with DAPI (blue fluorescence)

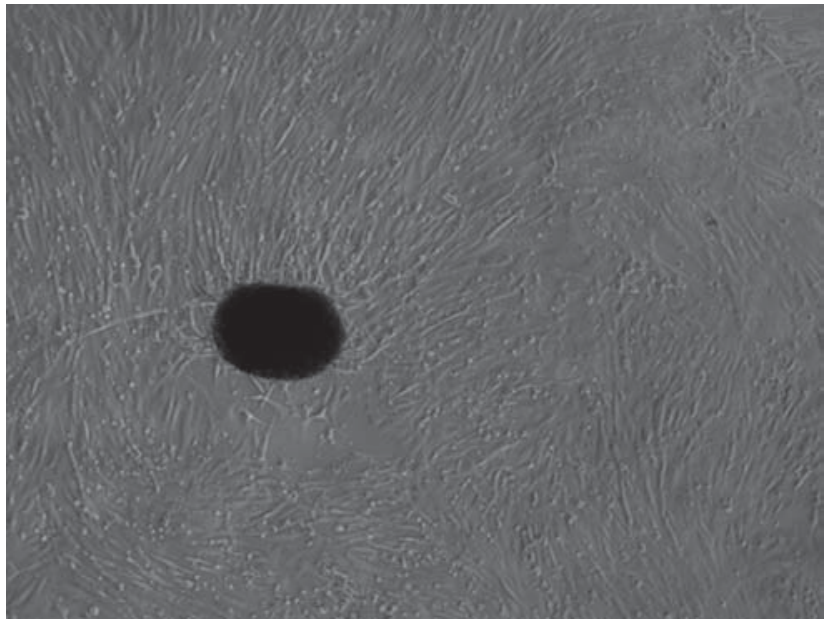

Fig. 16. Secondary culture on the poly-D-lysine coated dishes of the cardiosphere forming cells derived from the right ventricle

that mesenchymal stem cells can be very important for the proper development and growth of cardiac stem cells, which can be an important factor in the application of cardiac stem cells in the regenerative therapy of diseased heart.

Regardless of the differences in the phenotype of isolated cells, it should be noted that the number of c-kit positive cells in the heart is very low, which can limit the use of cardiac stem cells as a therapeutic agent. For this reason, it is also important to identify the proper place for the cell isolation because the morphology of the cells and the growth potential can vary in relation to the place of origin, which means that the cells isolated from different parts of the heart can show different growth characteristics. There are a few studies discussing the phenotype and morphology of adult human

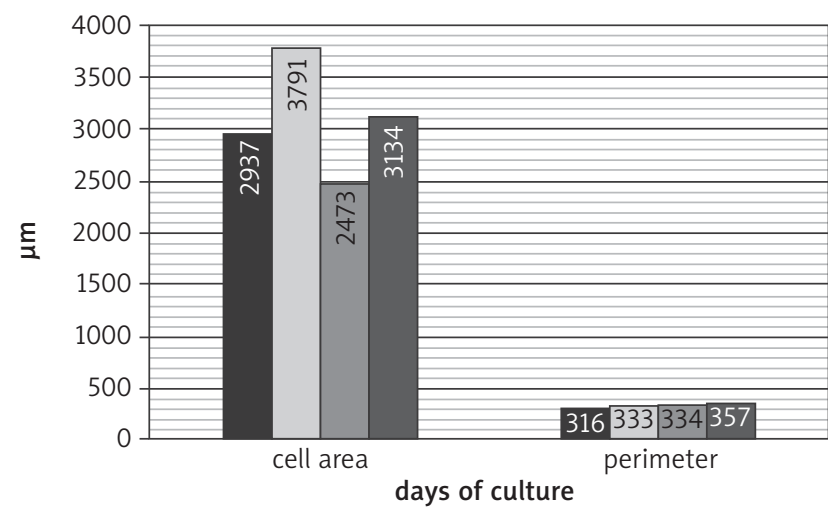

Fig. 17. Changes in the cell area and perimeter in the secondary culture on the poly-D-lysine coated dishes of the cardiosphere forming cells derived from the right ventricle on different days of culture

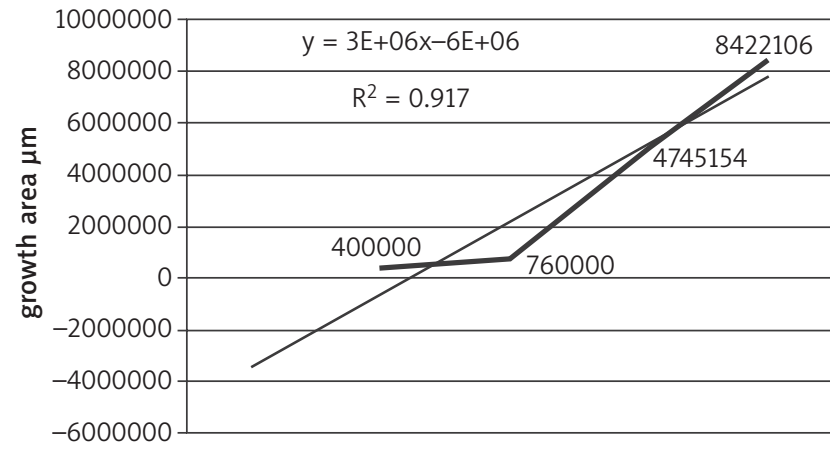

Fig. 18. Changes in the cell growth area in the secondary culture on the poly-D-lysine coated dishes of the cardiosphere forming cells derived from the right ventricle on different days of culture 


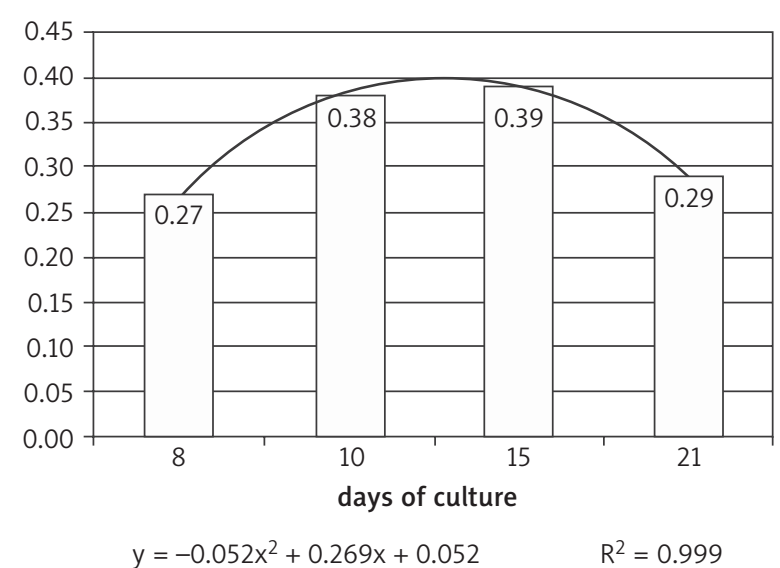

Fig. 19. Changes in the shape index in the secondary culture on the poly-D-lysine coated dishes of the cardiosphere forming cells derived from the right ventricle on different days of culture

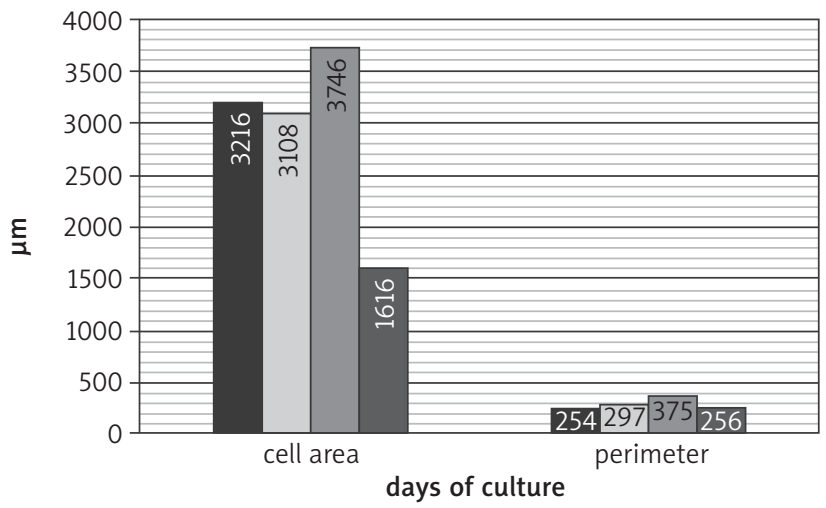

Fig. 21. Changes in the cell area and perimeter in the secondary culture on the poly-D-lysine coated dishes of the cardiosphere forming cells derived from the apex on different days of culture

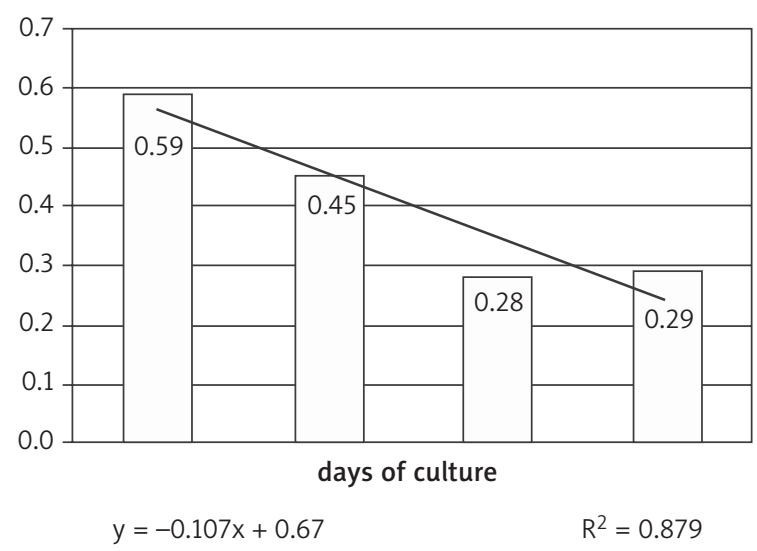

Fig. 23. Changes in the shape index in the secondary culture on the poly-D-lysine coated dishes of the cardiosphere forming cells derived from the apex on different days of culture

cardiomyocytes. In the study of Bird et al. [10] the phenotype of adult human atrial and ventricular myocytes based on gene expression and morphology was investigated. The atrial and ventricular cardiomyocytes were obtained during cardiac

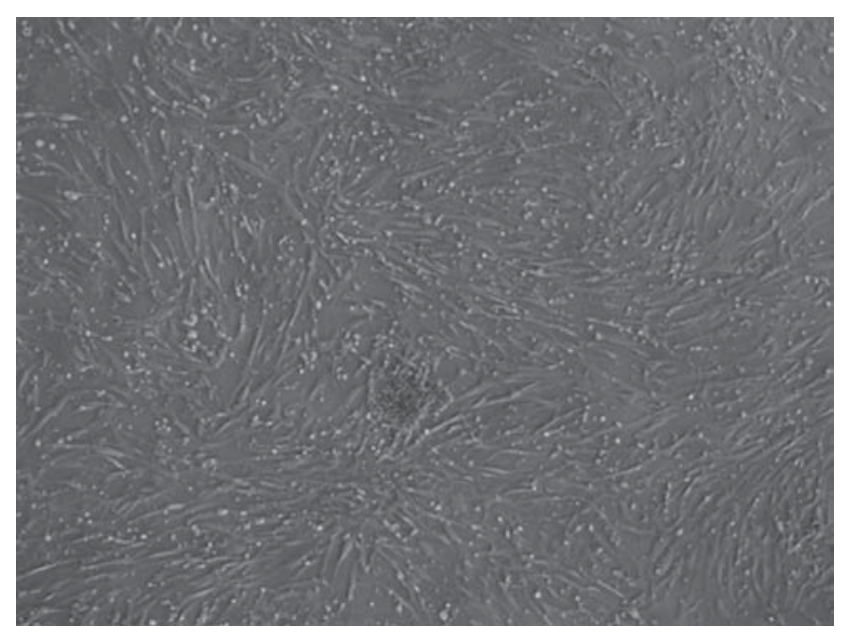

Fig. 20. Secondary culture on the poly-D lysine coated dishes of the cardiosphere forming cells derived from the apex

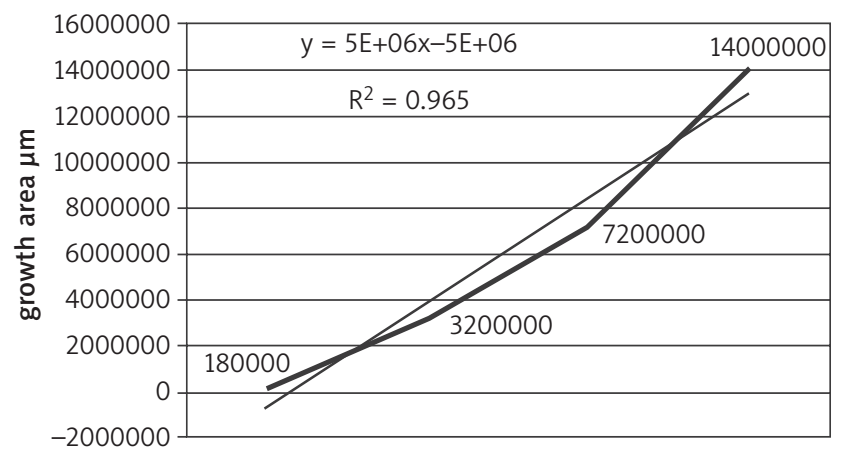

Fig. 22. Changes in the cell growth area in the secondary culture on the poly-D-lysine coated dishes of the cardiosphere forming cells derived from the apex on different days of culture

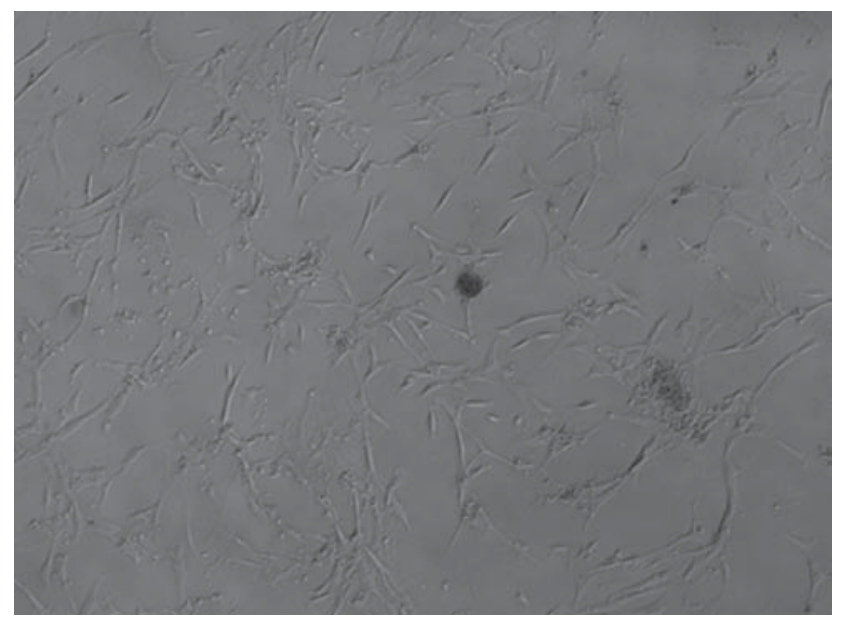

Fig. 24. Secondary culture on the poly-D-lysine coated dishes of the cardiosphere forming cells derived from the left ventricle

surgery. The cells were then cultured in different conditions in the culture medium with and without serum. In the study the relative cell attachment, the morphological changes dur- 


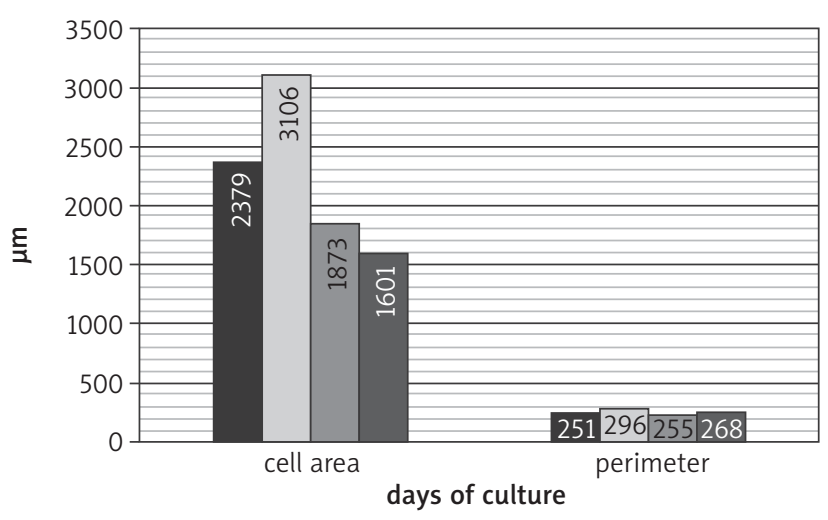

Fig. 25. Changes in the cell area and perimeter in the secondary culture on the poly-D-lysine coated dishes of the cardiosphere forming cells derived from the left ventricle on different days of culture

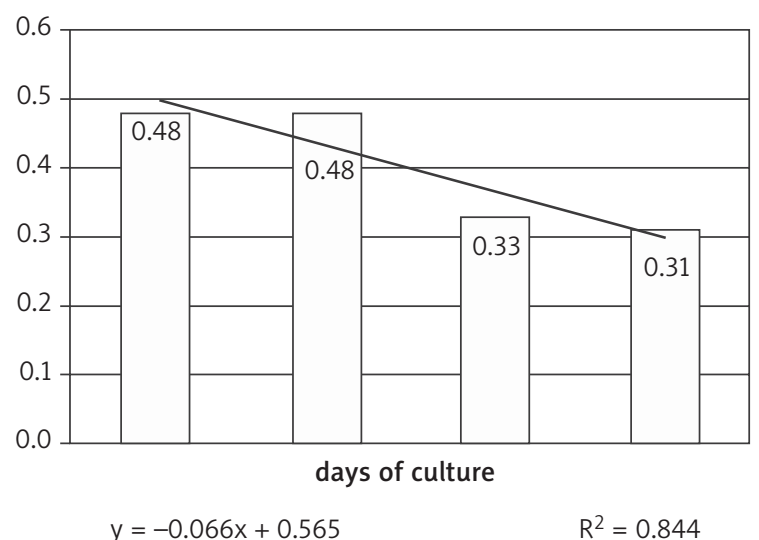

Fig. 27. Changes in the shape index in the secondary culture on the poly-D-lysine coated dishes of the cardiosphere forming cells derived from the left ventricle on different days of culture

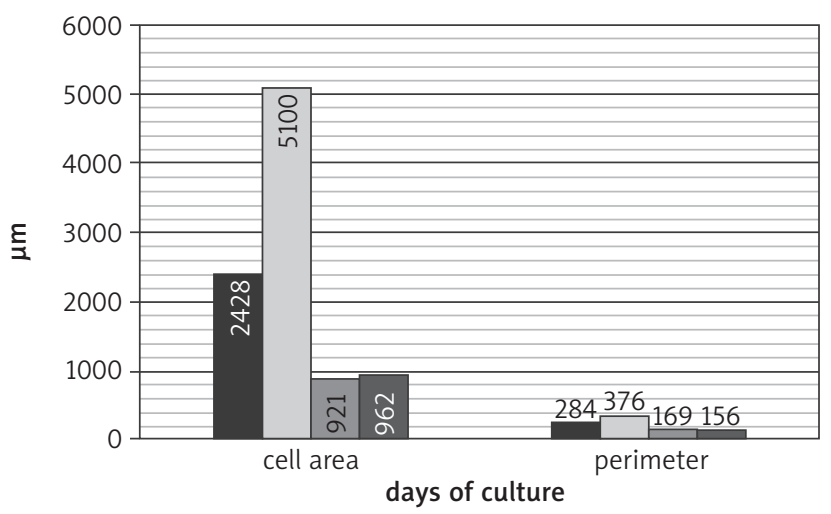

Fig. 29. Changes in the cell area and perimeter in the secondary culture on the poly-D-lysine coated dishes of the cardiosphere forming cells derived from the right atrium on different days of culture

ing long-term culture, sarcomeric markers including $\alpha$-actin, myosin light chain, adhesion molecules and cadherin were analyzed. After the isolation they observed the rod-shaped atrial and ventricular cells with significant numbers of apoptotic and necrotic cells. The dedifferentiation process in the cell culture was observed, which was indicated by the loss of sarcomeric structure and condensation of sarcomeric proteins.

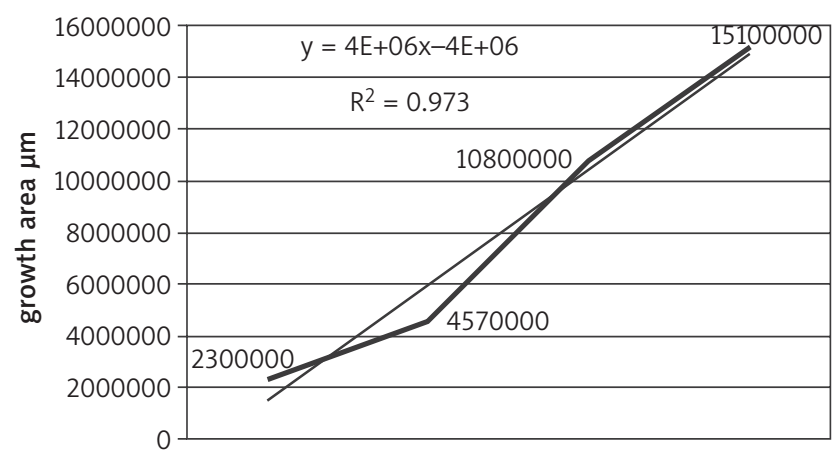

Fig. 26. Changes in the cell growth area in the secondary culture on the poly-D-lysine coated dishes of the cardiosphere forming cells derived from the left ventricle on different days of culture

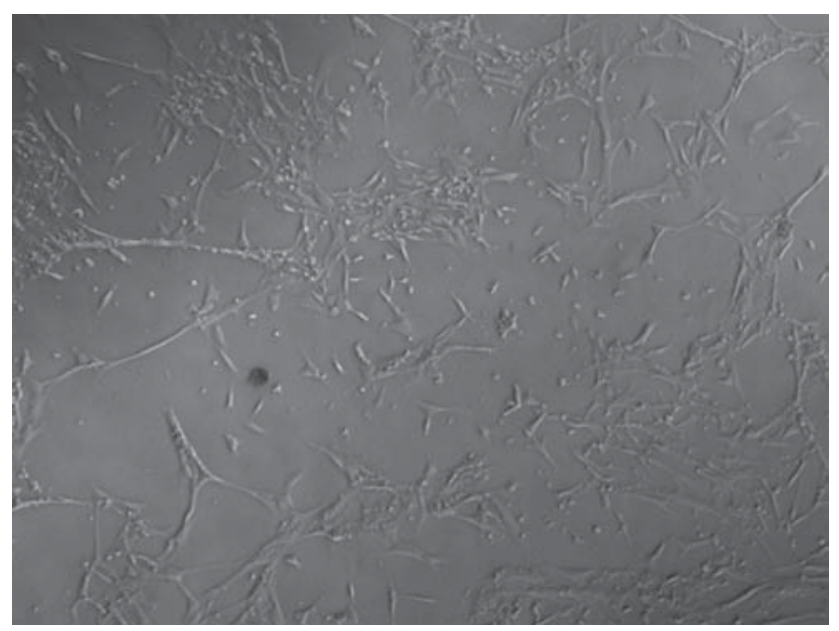

Fig. 28. Secondary culture on the poly-D-lysine coated dishes of the cardiosphere forming cells derived from the right atrium

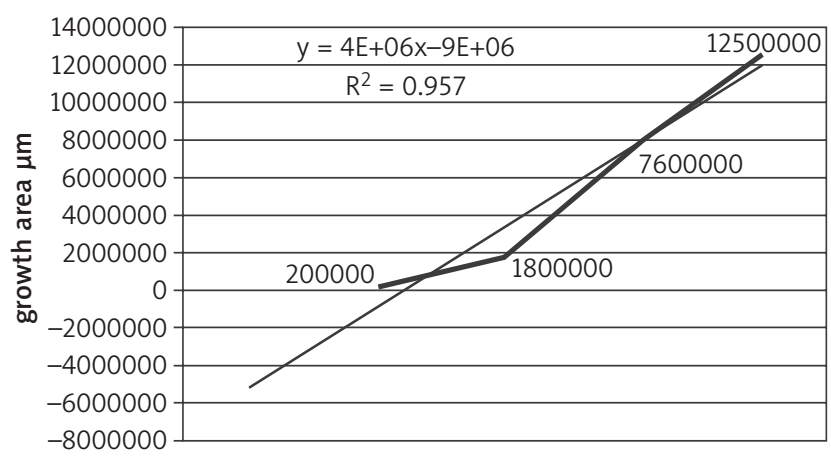

Fig. 30. Changes in the cell growth area in the secondary culture on the poly-D-lysine coated dishes of the cardiosphere forming cells derived from the right atrium on different days of culture

The culture conditions affect the morphology of the cells. In the low serum culture the cells are flattened and spread. Two distinct types of cells were observed in the culture: type I was large with extensive sarcolemmal spreading with stress fibers, while type II cells were smaller with mature myofibrils and focal adhesions. As seen from the above studies, the culture conditions and the time of culture can influence the car- 


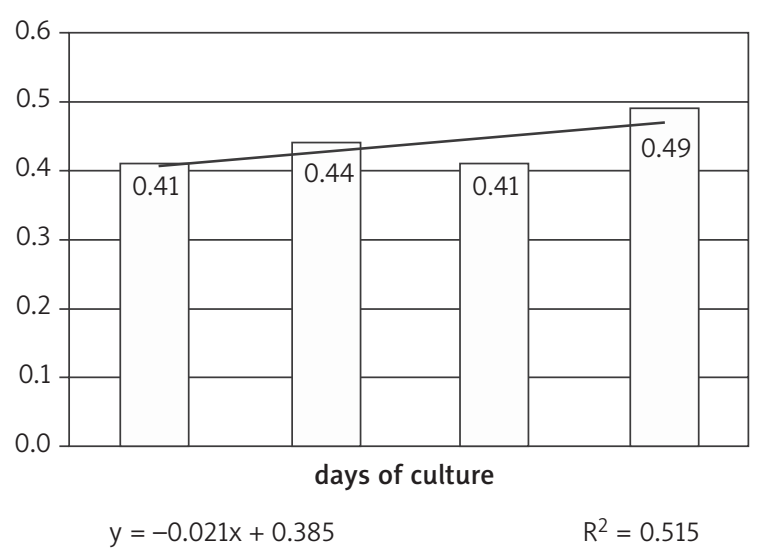

Fig. 31. Changes in the shape index in the secondary culture on the poly-D-lysine coated dishes of the cardiosphere forming cells derived from the right atrium on different days of culture

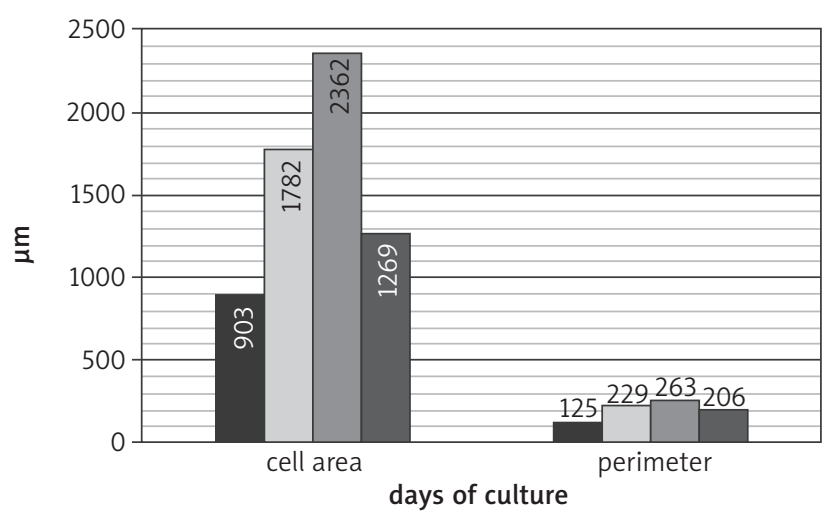

Fig. 33. Changes in the cell area and perimeter in the secondary culture on the poly-D-lysine coated dishes of the cardiosphere forming cells derived from the septum on different days of culture

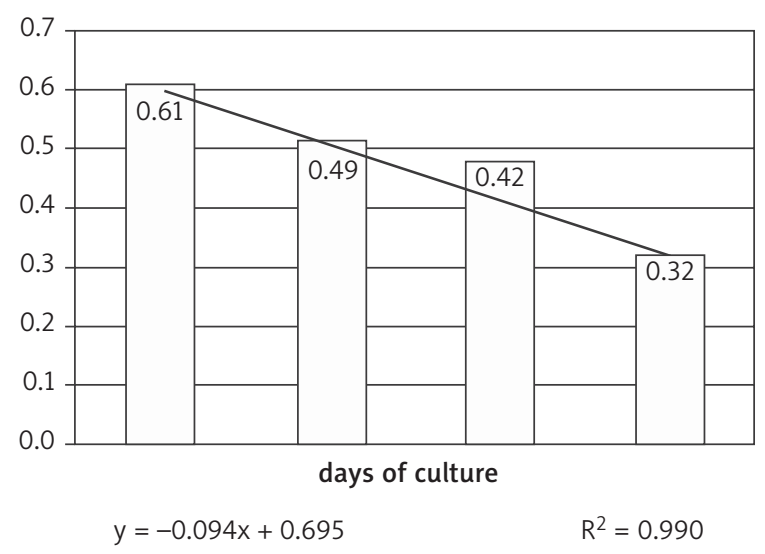

Fig. 35. Changes in the shape index in the secondary culture on the poly-D-lysine coated dishes of the cardiosphere forming cells derived from the septum on different days of culture

diac phenotype and morphometric properties. Another factor which can be very important for cardiomyocyte development is the mechanical factor. The cardiac cells are subjected to mechanical forces from early development and they are very

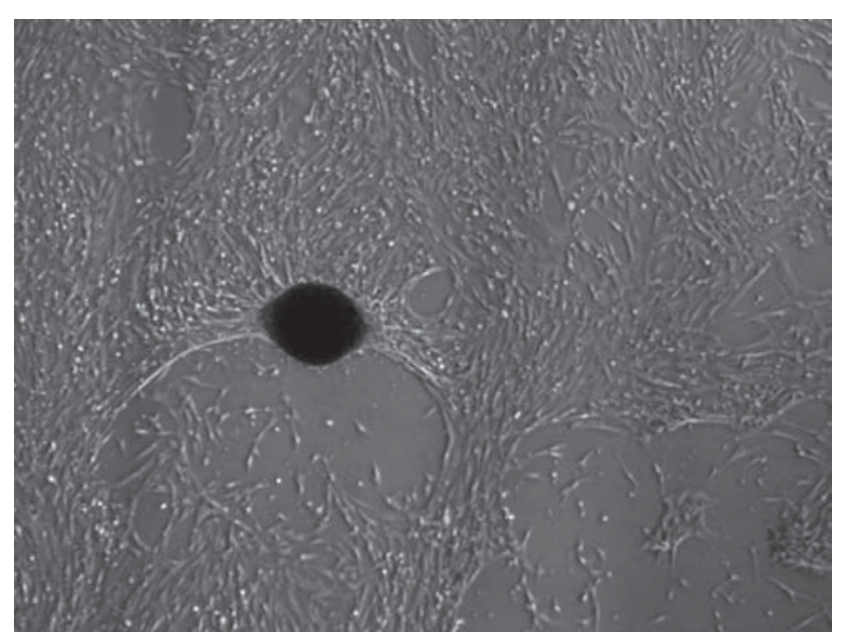

Fig. 32. Secondary culture on the poly-D-lysine coated dishes of the cardiosphere forming cells derived from the septum

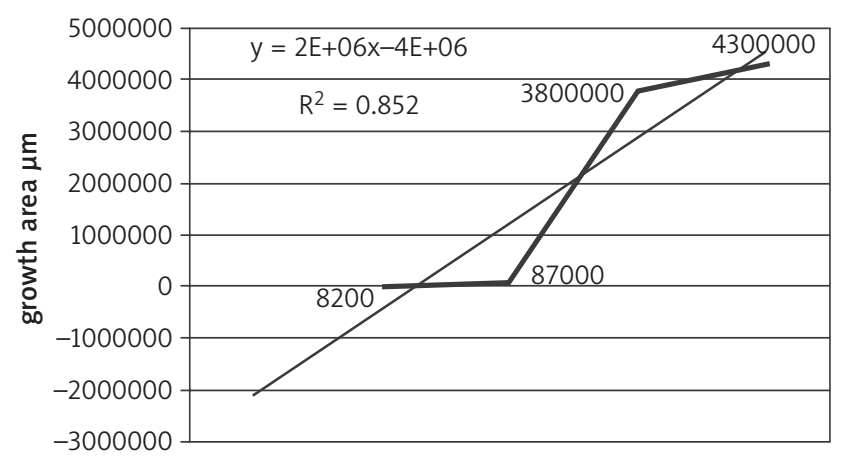

Fig. 34. Changes in the cell growth area in the secondary culture on the poly-D-lysine coated dishes of the cardiosphere forming cells derived from the septum on different days of culture

sensitive to the surrounding cardiac tissue. In the study of Jacot et al. [11] the mechanobiology of cardiomyocyte development was investigated. The effect of direct stretching, electrically induced beating and substrate stiffening was analyzed. The left ventricle from Black Swiss mice was isolated and the elastic modulus of epicardium was measured from embryonic day 13.5 to postnatal day 14 . The elastic modulus significantly changed during this period. In embryonic mice the value was $12 \pm 4 \mathrm{kPa}$ and it increased in neonatal mice to the value of $39 \pm 7 \mathrm{kPa}$. This study clearly indicates that mechanobiological factors can strongly affect the development of neonatal cardiomyocytes.

In our study we tried to indicate that if the different areas of cardiac muscle differ in properties including blood pressure, tissue thickens, which can influence the tissue elasticity and the mechanobiological properties of the surrounding tissue, and the cells isolated from atrium, ventricle, septum or apex can have different morphology and growth characteristics. Using the morphometric examination we observed the differences in morphology of cells isolated and cultured from different parts of the myocardium, and also the growth potential expressed as the growth 
rate, increase in cell area, perimeter or shape index was observed. Differences were observed both for the primary and secondary culture of the cardiac cells. It seems that this information can be valuable for the optimization of the cell culture of cardiac cells, and in the future can increase the application potential of regenerative therapy of diseased heart by using cardiac stem cells.

\section{Conclusions}

Cardiac stem/progenitor cells are an important group of cells with significant therapeutic properties which can be used in the treatment of diseased heart. But the morphology of the cells and growth characteristics differ in relation to the area of isolation. It seems to be important to check whether these differences may affect the therapeutic effect, and which area of the heart muscle has the greatest potential for isolation and culture of cardiac stem/progenitor cells.

The projecy was financed by scientific-research grant NN 403283336 from National Science Centre and grant KNW-1$-180 / 10$ from the Silesian Medical University.

\section{References}

1. Beltrami AP, Barlucchi L, Torella D, Baker M, Limana F, Chimenti S, Kasahara H, Rota M, Musso E, Urbanek K, Leri A, Kajstura J, Nadal-Ginard B, Anversa P. Adult cardiac stem cells are multipotent and support myocardial regeneration. Cell 2003; 114: 763-766.

2. Matsuura K, Nagai T, Nishigaki N, Oyama T, Nishi J, Wada H, Sano M, Toko H, Akazawa H, Sato T, Nakaya H, Kasanuki H, Komuro I. Adult cardiac Sca1-positive cells differentiate into beating cardiomycytes. J Biol Chem 2004; 279: 11384-11391.
3. Linke A, Müller P, Nurzynska D, Casarsa C, Torella D, Nascimbene A, Castaldo C, Cascapera S, Böhm M, Quaini F, Urbanek K, Leri A, Hintze TH, Kajstura J, Anversa P. Stem cells in the dog heart are self-renewing, clonogenic, and multipotent and regenerate infarcted myocardium, improving cardiac function. Proc Natl Acad Sci U S A 2005; 102: 8966-8971.

4. Urbanek K, Rota M, Cascapera S, Bearzi C, Nascimbene A, De Angelis A, Hosoda T, Chimenti S, Baker M, Limana F, Nurzynska D, Torella D, Rotatori F, Rastaldo R, Musso E, Quaini F, Leri A, Kajstura J, Anversa P. Cardiac stem cells possess growth factor-receptor systems that after activation regenerate the infarcted myocardium, improving ventricular function and longterm survival. Circ Res 2005; 97: 663-673.

5. Rosenblatt-Velin N, Lepore MG, Cartoni C, Beermann F, Pedrazzini T. FGF-2 controls the differentiation of resident cardiac precursors into functional cardiomyocytes. J Clin Invest 2005; 115: 1724-1733.

6. Urbanek K, Quaini F, Tasca G, Torella D, Castaldo C, Nadal-Ginard B, Leri A, Kajstura J, Quaini E, Anversa P. Intense myocyte formation from cardiac stem cells in human cardiac hypertrophy. Proc Natl Acad Sci U S A 2003; 100: 10440-10445.

7. Urbanek K, Torella D, Sheikh F, De Angelis A, Nurzynska D, Silvestri F, Beltrami CA, Bussani R, Beltrami AP, Quaini F, Bolli R, Leri A, Kajstura J, Anversa P. Myocardial regeneration by activation of multipotent cardiac stem cells in ischemic heart failure. Proc Natl Acad Sci U S A 2005; 102: 8692-8697.

8. Smith RR, Barile L, Cho HC, Leppo MK, Hare JM, Messina E, Giacomello A, Abraham MR, Marbán E. Regenerative potential of cardiosphere-derived cells expanded from percutaneous endomyocardial biopsy specimens. Circulation 2007; 115: 896-908.

9. Tateishi K, Ashihara E, Honsho S, Takehara N, Nomura T, Takahashi T, Ueyama T, Yamagishi M, Yaku H, Matsubara H, Oh H. Human cardiac stem cells exhibit mesenchymal features and are maintained through Akt/GSK-3beta signaling. Biochem Biophys Res Commun 2007; 352: 635-641.

10. Bird SD, Doevendans PA, van Rooijen MA, Brutel de la Riviere A, Hassink RJ, Passier R, Mummery CL. The human adult cardiomyocyte phenotype. Cardiovascular Res 2003; 58: 423-434.

11. Jacot GJ, Martin JC, Hunt DL. Mechanobiology of cardiomyocyte development. J Biomech 2010; 43: 93 . 